\title{
"Area 51: An Uncensored History of America's Top Secret Military Base," Annie Jacobsen (New York: Little, Brown and Company, 2011)
}

Edward M. Roche

Henley-Putnam University

Follow this and additional works at: https://digitalcommons.usf.edu/jss

Part of the Defense and Security Studies Commons, National Security Law Commons, and the Portfolio and Security Analysis Commons

pp. 73-74

\section{Recommended Citation}

Roche, Edward M.. "'Area 51: An Uncensored History of America's Top Secret Military Base," Annie Jacobsen (New York: Little, Brown and Company, 2011)." Journal of Strategic Security 4, no. 3 (2011) : 73-74. DOI:

http://dx.doi.org/10.5038/1944-0472.4.3.7

Available at: https://digitalcommons.usf.edu/jss/vol4/iss3/8

This Book Review is brought to you for free and open access by the Open Access Journals at Digital Commons @ University of South Florida. It has been accepted for inclusion in Journal of Strategic Security by an authorized editor of Digital Commons @ University of South Florida. For more information, please contact digitalcommons@usf.edu. 
"Area 51: An Uncensored History of America's Top Secret

Military Base," Annie Jacobsen (New York: Little, Brown and Company, 2011) 


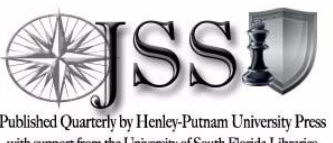

Published Quartilly by Henly-Putnam University Pres

\section{Area 51: An Uncensored History of America's Top Secret Military Base. By Annie Jacobsen. New York: Little, Brown and Company, 2011. ISBN: 978-0-316-13294-7. Photographs. Notes. Sources. Index. Pp. 544. \$27.99.}

Area 51 is associated in the public mind with the Roswell crash of a UFO and an enduring government cover-up. As this well-researched book shows, the U.S. Government definitely has been covering up what has happened in this part of Nevada, but not because of aliens. Instead, the habitual obfuscation, which continues today, was set up so that the U.S. intelligence community could develop surveillance technologies.

The bulk of the story concerns the development by the CIA of the "Oxcart," a high-altitude (90,00o feet) aircraft, built of titanium smuggled out of Russia, that could fly from New York to Los Angeles in 70 minutes and remain undetectable to radar. The various sightings of UFOs occurred when civilian airline pilots flying along at a mere 300 miles per hour at 30,000 feet would see the craft in twilight as the setting sun's rays reflected off of its underbody. After calling in the "UFO" sighting, the crew of the airliner would be met by the FBI at the next airport and forced to sign national security non-disclosure agreements. The speed records for the "Oxcart" were not broken until the 21st century.

The story of UFOs was encouraged by the government as a way to keep speculation away from the intelligence angle, and the Air Force "Project Blue Book" was forced to manufacture ridiculous stories such as "what they saw was swamp gas." From Area 51, the CIA flew some 2,800 missions with these aircraft which were never detected, although somehow Soviet intelligence seemed aware.

In addition, a wide variety of experiments has been conducted involving nuclear weapons, radar, stealth technologies, and reverse engineering of captured Soviet aircraft. Examples include development of a space aircraft that would be powered by nuclear explosions, extensive and possibly illegal underground testing of nuclear weapons, development of the F-117 Nighthawk stealth aircraft, and pioneering of the drones that today are playing such an important role in the Af-Pak region. One of the most peculiar discussions concerns the Soviet "flying saucer," an aircraft which was developed in Russia by captured German engineers, and flown to the 
United States carrying humans that had been physically altered by Nazi scientists to look like aliens. Lockheed examined these saucers and determined that their underlying design was not stable enough for space travel. The "flying wing" also was a related technology first developed in Germany, and then re-engineered in Area 51 and the "Skunk Works."

To a certain extent, the book also uncovers some dirty laundry. For example, it is well documented that the Air Force attempted to "kill" the CIA Oxcart project so that it could develop its own "SR-71" bomber and monopolize all intelligence surveillance. This self-serving plan almost succeeded until President Johnson ordered use of the Oxcart over Vietnam and North Korea because the Air Force could not deploy as quickly as could the CIA. There is also coverage of how the intelligence community deceived UFO watchers, including placing among them government persons as infiltrators to monitor and manipulate their opinions. The book starts with a discussion of what happened to one person who talked; their entire identity apparently was erased and they were made out to be insane. In addition, there is reporting on radiation and other tests conducted on U.S. citizens by the Atomic Energy Commission using imported Nazi scientists, who in the Third Reich had done horrible experiments on concentration camp victims. These tests are so highly classified that even the President of the United States cannot see the information.

Much of the data in this book can be supplemented by declassified information from the CIA. Many of the sources interviewed by the author also appear on a recently aired National Geographic special on Area 51 that can be seen on YouTube.

Apart from these sensationalistic revelations, the real story of Area 51 is the truly amazing scientific and engineering work. Plying their trade in very primitive conditions, in inhospitable weather, under secrecy so tight that even spouses could have no idea what was happening, these engineers and others developed technologies so revolutionary that they are almost unbelievable, and the work continues even today.

Study of the intelligence community is something like driving into the future using the rear-view mirror. What we see happened fifty years ago; gradually, a small portion is declassified, while most remains hidden. If such amazing technologies were developed so long ago, we can only wonder what is being developed now. The suspicion about Area 51 will not disappear. As one of the interviewees said, Area 51 is probably a cover-up for something else.

Edward M. Roche, Ph.D., J.D., Henley-Putnam University 